\title{
Design and Application of Underground Mine Paste Backfill Technology
}

\author{
Tikou Belem · Mostafa Benzaazoua
}

Published online: 20 December 2007

(C) Springer Science+Business Media B.V. 2007

\section{Erratum to: Geotech Geol Eng DOI 10.1007/s10706-007-9154-3}

Due to a regrettable error, a very important correction in the author name was not properly carried out in the last stage of the publication process of the abovementioned paper.
The first author's name is inadvertently displayed as Tikov Belem while the correct name should be Tikou Belem.

The publisher apologizes for this unfortunate mistake.

The online version of the original article can be found under doi:10.1007/s10706-007-9154-3.

T. Belem $(\bowtie) \cdot$ M. Benzaazoua

Department of Applied Sciences, Université du Québec en Abitibi-Témiscamingue (UQAT), 445, boul. de l'Université, Rouyn-Noranda, QC, Canada J9X 5E4

e-mail: tikou.belem@uqat.ca

M. Benzaazoua

Department of Applied Sciences, CRC on Integrated Management of Sulphidic Mine Tailings by Backfilling, UQAT, Rouyn-Noranda, Canada 